\title{
Frequency of Hepatitis B Virus, Hepatitis C Virus and HIV Infections in Cannabis and Opioid Addicts
}

\author{
Esrar ve Opiyat Bağımlılarında Hepatit B Virüsü, Hepatit C Virüsü ve HIV Enfeksiyonları \\ Sıklığı
}

\author{
Nuran KARABULUT1,2, Zekiye ÇATAK3 \\ 1 Elazığ Mental Health Hospital, Clinic of Medical Microbiology, Central Laboratory, Elazığ, Turkey \\ 2Istanbul University Istanbul Faculty of Medicine, Department of Medical Microbiology, Division of Virology and Fundamental Immunology, Istanbul, Turkey \\ ${ }^{3}$ Elazığ Mental Health Hospital, Clinic of Medical Biochemistry, Central Laboratory, Elazığ, Turkey
}

\begin{abstract}
Objective: There are very few data about the epidemiology of hepatitis $B$ virus (HBV), hepatitis $C$ virus $(\mathrm{HCV})$ and $\mathrm{HIV}$ infections in drug addicts in Turkey, whereas several countries have a developed surveillance systems to monitor the spread of HBV, HCV and HIV infections in drug users. In this study, HBV, HCV and HIV prevalence in cannabis and opioid addicts were investigated.

Materials and Methods: Hepatitis B surface antigen (HBsAg), anti$\mathrm{HBs}$, anti-HCV and anti-HIV tests were analyzed by enzyme-linked immunosorbent assay. The cannabis and opioid metabolites in urine samples of drug addicts were analyzed by cloned enzyme donor immunoassay.

Results: This retrospective study was conducted on 276 individuals with a mean age of $28.89 \pm 10.49$ years. $\mathrm{HBsAg}$, anti-HBs and anti-HCV prevalence in drug addicts was found to be $4 \%, 52.3 \%$ and $7.9 \%$, respectively. In all the drug addicts, anti-HIV test was negative. Whereas the rate of $\mathrm{HBsAg}$ among cannabis users (8.8\%) was higher than opioid $(4.1 \%)$ and both cannabis and opioid users $(1.4 \%)$, the difference was not statistically significant. Although antiHCV positivity among cannabis users was not detected, $6.4 \%$ of opioid users and $15.9 \%$ of both cannabis and opioid users were anti-HCV positive $(\mathrm{p}=0.009)$.

Conclusion: This study showed that HCV infection among especially opioid users and both cannabis and opioid users was a problem. Understanding of local status in HBV, HCV and HIV infections is crucial for developing prevention and geographical strategies for these infections.

Keywords: Drug addicts, cannabis, opioid, hepatitis B virus, hepatitis C virus, HIV
\end{abstract}

\section{$\ddot{0 Z Z}$}

Amaç: Bazı ülkelerde uyuşturucu kullanıııları arasında hepatit B virüs (HBV), hepatit C virüs (HCV) ve HIV enfeksiyonlarının yayılmasını izlemek için gelişmiş bir sürveyans sistemi mevcutken, Türkiye'de uyușturucu bağımlılarında HBV, HCV ve HIV enfeksiyonlarının epidemiyolojisi hakkında çok az veri mevcuttur. Bu çalışmanın amacl, esrar ve opiyat bağımlıları arasında HBV, HCV ve HIV sıklığını değerlendirmektir.

Gereç ve Yöntemler: Hepatit B yüzey antijeni (HBsAg), anti-HBs, antiHCV ve anti-HIV testleri, Enzyme-Linked Immunosorbent Assay tekniği ile analiz edildi. Uyuşturucu bağımlılarının idrar örneklerinde esrar ve opiyat metabolitleri, klonlanmış enzim donör immünoassay tekniği ile analiz edildi.

Bulgular: Bu retrospektif çalışma, yaş ortalaması $28,89 \pm 10,49$ olan 276 olgu üzerinde gerçekleştirildi. Uyuşturucu bağımlılarında HBsAg, anti-HBs ve anti-HCV sıklığı sırasıyla \%4, \%52,3 ve \%7,9 olarak tespit edildi. Tüm uyuşturucu bağımlılarında, anti-HIV testi negatifti. Esrar kullanıcıları arasında HBsAg sıklığı $(\% 8,8)$, opiyat $(\% 4,1)$ ve hem esrar hem de opiyat kullanıılardan $(\% 1,4)$ daha yüksek iken, bu fark istatistiksel olarak anlamlı değildi. Esrar kullanıcıarında antiHCV pozitifliği tespit edilmemesine rağmen, opiyat kullanıcılarının $\% 6,4$ 'ü hem esrar hem de opiyat kullanıcılarının \%15,9'u anti-HCV pozitifti $(p=0,009)$.

Sonuç: Bu çalışma özellikle opiyat kullanıcıları ile hem esrar hem de opiyat kullanıcıları arasında HCV enfeksiyonunun sorun olduğunu göstermiştir. HBV, HCV ve HIV enfeksiyonlarında lokal durumun anlaşılması, bu enfeksiyonların önlenmesi ve coğrafi olarak stratejilerin geliştirilmesi için önemlidir.

Anahtar Kelimeler: Uyușturucu bağımlıları, esrar, opiyat, hepatit B virüs, hepatit $\mathrm{C}$ virüs, HIV

Karabulut N, Catak Z. Frequency of Hepatitis B Virus, Hepatitis C Virus and Human Immunodeficiency Virus Infections in Cannabis and Opioid Addicts. Viral Hepat J. 2017;23:26-29.

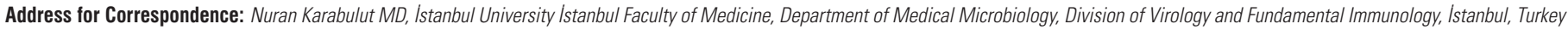
Phone: +90 5052613347 E-mail: nuranakarabulut@gmail.com Received: 15.02.2017 Accepted: 04.03.2017

${ }^{\circ}$ Copyright 2017 by Viral Hepatitis Society / Viral Hepatitis Journal published by Galenos Publishing House. 


\section{Introduction}

It is estimated that the number of cannabis and opioid users worldwide are 161 million and 16 million, respectively. Cannabis is the most consumed drug in the world (1). Cannabis or marijuana contains the psychoactive chemical delta-9-tetrahydrocannabinol, which is believed to be the main chemical component that produces the psychoactive effect. Cannabis is often used through smoking in hand-rolled cigarettes, pipes, or water pipes (2). Opioids contain hydrocodone, oxycodone, morphine, and codeine, and the illegal opioid, heroin. Heroin is a powerful opiate drug, and used through injecting, smoking, or snorting (3). Hepatitis B virus (HBV), hepatitis C virus (HCV) and HIV prevalence in the world varies depending on geographical location. Turkey is a medium endemic country for both HBV (2\%-8\%) and HCV (1\%-2\%). The prevalence of HIV infection in Turkey varies from region to region but still seems low $(1,4)$. On the other hand, since drug addicts show risky behaviors, including unsafe sex and risky injection practices, it is believed that there is a strong link between the spread of infectious diseases and drug abuse. The most important factor increasing their risk of HBV, HCV and HIV transmission is sharing drug preparation or injecting equipment (5). 50\%-80\% of $\mathrm{HCV}$ infection in the developed countries occurs among injection drug users (6). HCV infection is the most common blood-borne infection among drug addicts in the developed countries. HIV, less common than $\mathrm{HCV}$, can also be transmitted during unprotected sex. In several studies, high HBV, HCV and HIV prevalence was described among drug users in the several countries $(7,8,9,10)$. However, there is not enough knowledge about the epidemiology of these infections in drug addicts in Turkey, whereas several countries have a developed surveillance systems to monitor the spread of HBV, HCV and HIV infections in drug users. Therefore, in this study, it was aimed to investigate the frequency of $\mathrm{HBV}, \mathrm{HCV}$ and HIV infections in cannabis and opioid addicts admitted to the drug addiction treatment center at Elazığ Mental Health Hospital.

\section{Materials and Methods}

\section{Subjects}

This retrospective study included 276 drug addicts in Drug Addiction Treatment Centre at Elazığ Mental Health Hospital in 2015. There is a drug addiction treatment center providing medical care and social support for drug addicts in the hospital. This study was approved by Firat University Ethics Committee (08/11/26.04.2016).

\section{Serological Analysis}

Blood samples collected from the drug users were analyzed in the center clinical laboratory of the hospital. Hepatitis B surface antigen (HBsAg), anti-HBs, anti-HCV (GBC, Taiwan, ROC) and anti-HIV (DIA.PRO, Milano, Italy) tests were performed by enzymelinked immunosorbent assay using the Triturus analyzer (Grifols, Parets del Valles, Spain). Each study included both positive and negative controls. For HBsAg, anti-HCV and anti-HIV parameters, samples with a cut-off value of $<1$ were considered negative and samples with a cut-off value of $\geq 1$ were considered positive. For anti-HBs, samples with $<10 \mathrm{mlU} / \mathrm{mL}$ were considered negative and samples with $\geq 10 \mathrm{mlU} / \mathrm{mL}$ were considered positive. The samples detected to be positive in the first run were tested again. For samples which were repeatedly positive for HIV, the results were confirmed by the Western blot test.

\section{Drug Analysis}

The cannabis and opioid metabolites in urine samples of drug addicts were analyzed in the center clinical laboratory of the hospital. All tests for drug detection (CEDIA, Fremont, USA) were performed by cloned enzyme donor immunoassay, using the Roche Hitachi Modular P800 analyzer (Diamond Diagnostics, Holliston, USA).

\section{Statistical Analysis}

Statistical analyses were performed by SPSS 20 (SPSS Inc, Chicago, USA). The differences in results between two groups were assessed by the chi-square test. The Kruskal-Wallis test was performed to compare hepatitis parameters between cannabis, opioid and mixed drug users. A p value of less than 0.05 was considered statistically significant.

\section{Results}

All the 276 drug addicts in the study were male and the mean age of the subjects was $28.89 \pm 10.49$ years (range: $18-68$ years). As shown in Table 1, 34 and 173 drug addicts who were admitted drug addiction treatment center have used only cannabis and only opioid, respectively. The number of mixed drugs users in whom both cannabis and opioid metabolites were detected in the urine samples was $69.55 .9 \%$ of cannabis users, $53.8 \%$ of opioid users and $47.8 \%$ of both cannabis and opioid users were in the $20-29$ age group (Figure 1).

In drug addicts, HBsAg, anti-HBs and anti-HCV rates were $4 \%, 52.3 \%$ and $7.9 \%$, respectively. Anti-HIV test was negative in all the drug addicts. HBV and HCV rates among cannabis, opioid and mixed drugs users are shown in Table 2. Whereas the rate of HBsAg among cannabis users (8.8\%) was higher than opioid $(4.1 \%)$ and mixed drugs users $(1.4 \%)$, this difference was not

Table 1. Drug use distribution

\begin{tabular}{|l|l|l|}
\hline Drug use & The number of subject & Percentage (\%) \\
\hline Cannabis only & 34 & 12.3 \\
\hline Opioid only & 173 & 62.7 \\
\hline Mixed drugs & 69 & 25.0 \\
\hline Mixed drugs: Both cannabis and opioid users \\
\hline
\end{tabular}

Table 2. The frequency of hepatitis B surface antigen, anti-HBs and antihepatitis $C$ virus among drug users

\begin{tabular}{|l|l|l|l|l|l|}
\hline & $\begin{array}{l}\text { Overall } \\
\mathbf{n}(\%)\end{array}$ & $\begin{array}{l}\text { Cannabis } \\
\text { only } \\
\mathbf{n}(\%)\end{array}$ & $\begin{array}{l}\text { Opioid } \\
\text { only } \\
\mathbf{n}(\%)\end{array}$ & $\begin{array}{l}\text { Mixed } \\
\text { drugs } \mathbf{n} \\
(\%)\end{array}$ & $p$ \\
\hline $\begin{array}{l}\text { HBsAg } \\
\text { positive }\end{array}$ & $11(4)$ & $3(8.8)$ & $7(4.1)$ & $1(1.4)$ & 0.200 \\
\hline $\begin{array}{l}\text { Anti-HBs } \\
\text { positive }\end{array}$ & $145(52.3)$ & $18(52.9)$ & $91(52.6)$ & $36(52.2)$ & 0.997 \\
\hline $\begin{array}{l}\text { Anti-HCV } \\
\text { positive }\end{array}$ & $22(7.9)$ & 0 & $11(6.4)$ & $11(15.9)$ & 0.009 \\
\hline
\end{tabular}

Mixed drugs: both cannabis and opioid users, HBsAg: Hepatitis B surface antigen, HCV: Hepatitis C virus 
statistically significant. The rate of anti-HBs among cannabis, opioid and mixed drugs users was similar $(52.9 \%, 52.6 \%$ and $52.2 \%$, respectively). Whereas cannabis users were anti-HCV-negative, $6.4 \%$ of opioid users and $15.9 \%$ of mixed drugs users were antiHCV positive $(\mathrm{p}=0.009)$.

The highest HBsAg seropositivity was detected in the 40-49 age group while the highest anti-HCV seropositivity was determined in the 40-49 group and in those older than 50 years of age. Seropositivity of HBsAg and anti-HCV was not detected in the $<20$ age group (Figure 2). The frequency of anti-HBs was found to be $80.4 \%$ in the $<20$ age group (Figure 3 ).

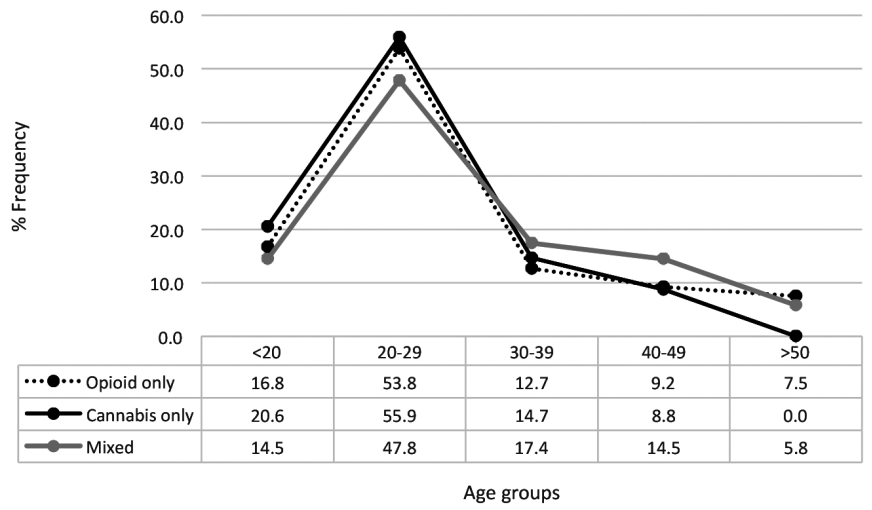

Figure 1. The distribution of according to age groups of drug users

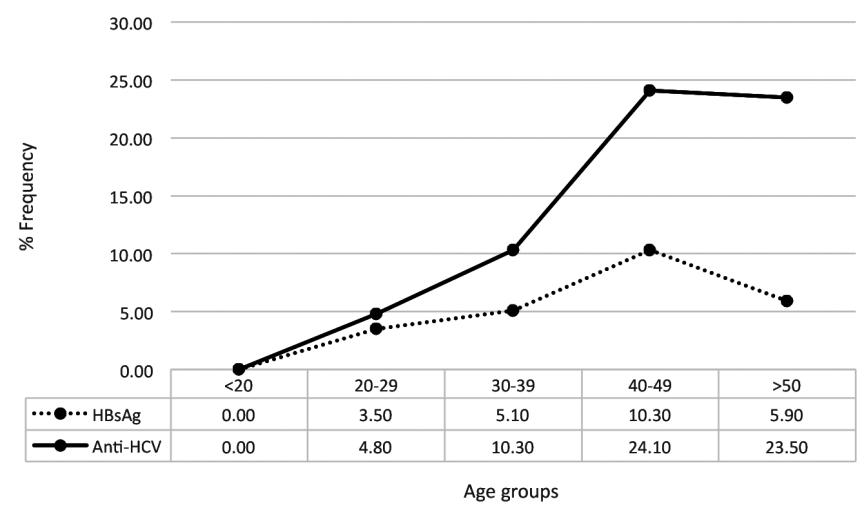

Figure 2. The frequency of hepatitis B surface antigen and anti-HCV in age groups

HBsAg: Hepatitis B surface antigen

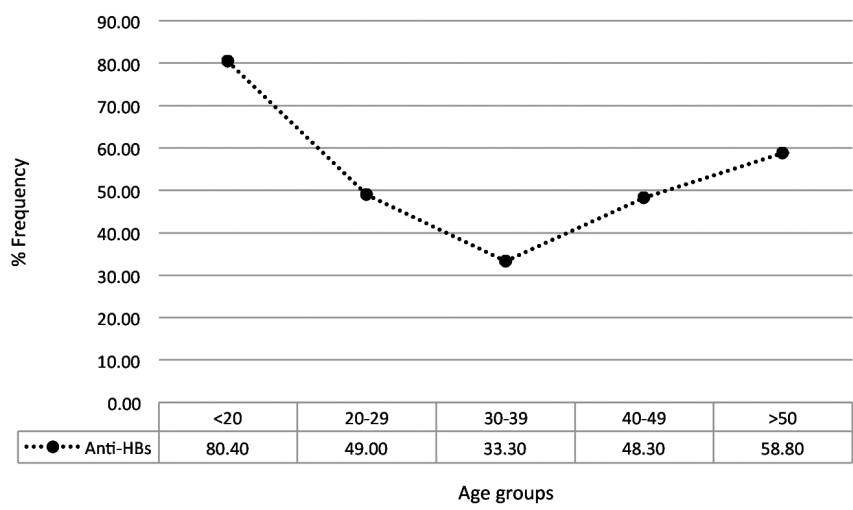

Figure 3. The frequency of anti-HBs in age groups

\section{Discussion}

HBV, HCV and HIV infections are a serious problem among drug addicts and remain an important public health issue. The high HBV, HCV and HIV prevalence among drug users in various parts of the world is still at the alarming rate. Unfortunately, there is limited data about HBV, HCV and HIV prevalence in drug addicts in Turkey. In our previous study performed between September 2011 and October 2012, HBsAg, anti-HBs and anti-HCV frequency in drug addicts were found to be $2.6 \%, 38.3 \%$ and $9.4 \%$, respectively. Additionally, anti-HIV positivity was not detected (1). The present study showed that the frequency rate of HBsAg, anti-HBs and anti-HCV in drug addicts was $4 \%, 52.3 \%$ and $7.9 \%$, respectively. All the drug addicts in this study were HIV-negative, and this result might be related to the size of the HIV reservoir in Turkey. HBV and HCV are more stable in environmental conditions and transmitted more easily than HIV. The incidence rates for HBV and HCV infections are also typically much higher than HIV infection (11).

HBV and HCV prevalence in injecting drug users varies between regions in Europe over $40 \%$ and $40-90 \%$, respectively. In a study carried out in Luxembourg, it was detected that the prevalence of HCV was $81.3 \%$ in injecting drug users and $19.1 \%$ in non-injecting drug users. The authors claimed that these results put Luxembourg in the upper range of the prevalence of $\mathrm{HCV}$ among injecting drug users in Europe (7). In the European Economic Area and the European Union, the estimated HIV prevalence among injecting drug users ranges from less than $1 \%$ to more than $60 \%$. A significant increase in HIV infection among injecting drug users in Greece and Romania in 2011 has been reported (8). A serious increase in the number of newly diagnosed HIV infection among injecting drug users, more than 10-fold, was reported in Greece during the first seven months of 2011 (9). In the United States, HCV seroprevalence has been reported in 18\%$38 \%$ of shorter duration injection drug users and $75 \%-90 \%$ of long-term injection drug users (10).

The high HBV, HCV and HIV prevalence in drug addicts depends on multiple factors, including the number of needlesharing partners, the frequency of needle sharing and the social network structures among drug addicts. Additionally, the types of drugs, risky sexual behaviors, the size of the drug addicts population, and awareness of risks and prevention measures are other important factors. In a study conducted among drug users in St. Petersburg, Russia, it was shown that the type of the injected drug was associated with the prevalence and incidence of HIV infection (12). In the present study, whereas anti-HCV was not detected among cannabis users, $6.4 \%$ of opioid users and $15.9 \%$ of mixed drugs users were anti-HCV positive. This study showed that the type of drug has an effect on the rate of anti-HCV.

This study showed that the highest rate of drug use was in the 20-29 age group. Therefore, effective programs preventing $\mathrm{HBV}$ and $\mathrm{HCV}$ infection among drug addicts should target young persons. Additionally, our results were consistent with previous studies $(10,13)$ which demonstrated that frequency of anti-HCV increases with age. This status may be related to the duration of drug use. Longer duration of drug use may lead to more sharing of needles and other equipment, resulting in a greater likelihood of transmission. On the other hand, this study showed that the rate 
of anti-HBs positivity was $80.4 \%$ in those younger than 20 years of age. In Turkey, hepatitis B vaccine was included in the national vaccination program in 1998. While the vaccine is given to any adult in the risk groups who desires protection, all infants are vaccinated with three doses $(14,15)$.

\section{Study Limitations}

This study had several limitations. The tests showing acute or chronic infection could not be performed. Tests distinguishing HBV vaccine from past HBV infection could not be performed in anti-HBs positive patients. Lastly, the risk factors for transmission of HBV and HCV transmission could not be determined among the drug addicts due to the retrospective design of the study.

\section{Conclusion}

This study demonstrated that HBV and HIV prevalence among drug addicts was not higher than in the general population in Turkey. However, it may be said that HCV infection among especially opioid users and mixed drugs users was a problem. Reducing HBV, HCV and HIV transmission among drug users should be an important public health objective. Understanding of local status in HBV, HCV and HIV infections is important for developing prevention strategies.

\section{Ethics}

Ethics Committee Approval: This study was appoved by the Firat University Ethical Committee, 08/11/26.04.2016, Informed Consent: This study was a retrospective and no informed consent was obtained.

Peer-review: Internally peer-reviewed.

\section{Authorship Contributions}

Surgical and Medical Practices: N.K., Concept: N.K., Design: N.K., Data Collection or Processing: N.K., Z.Ç., Analysis or Interpretation: N.K., Z.Ç., Literature Search: N.K., Z.Ç., Writing: N.K.

Conflict of Interest: No conflict of interest was declared by the authors.

Financial Disclosure: The authors declared that this study received no financial support.

\section{References}

1. Karabulut $N$, Bulut $Y$, Telo $S$. Frequency of Hepatitis $B$ and $C$ Viruses, and HIV Among Drug Addicts in the Eastern Anatolia, Turkey. Jundishapur J Microbiol. 2015;8:e19698.

2. Administration SAAMHS. Cannabis [21.03.2016]. Available from: http://www.samhsa.gov/atod/cannabis.

3. Administration SAAMHS. Opioids [21.03.2016]. Available from: http://www.samhsa.gov/atod/opioids.

4. Karabulut N. Prevalence of HBV, HCV and HIV in Inpatients of a Mental Health Hospital in Turkey, 2011-2013. Iran J Public Health. 2015;44:1026-1028.
5. Tempalski B, Pouget ER, Cleland CM, Brady JE, Cooper HL, Hall HI, Lansky A, West BS, Friedman SR. Trends in the population prevalence of people who inject drugs in US metropolitan areas 1992-2007. PLoS One. 2013;8:e64789.

6. Robaeys G, Grebely J, Mauss S, Bruggmann P, Moussalli J, De Gottardi A, Swan T, Arain A, Kautz A, Stover H, Wedemeyer H, Schaefer M, Taylor L, Backmund M, Dalgard O, Prins M, Dore GJ; International Network on Hepatitis in Substance Users. Recommendations for the management of hepatitis $\mathrm{C}$ virus infection among people who inject drugs. Clin Infect Dis. 2013;57 (Suppl 2):S129-137.

7. Removille $N$, Origer A, Couffignal S, Vaillant M, Schmit JC, Lair ML. A hepatitis A, B, C and HIV prevalence and risk factor study in ever injecting and non-injecting drug users in Luxembourg associated with HAV and HBV immunisations. BMC Public Health. 2011;11:351.

8. Pharris A, Wiessing L, Sfetcu O, Hedrich D, Botescu A, Fotiou A, Nikolopoulos GK, Malliori M, Salminen M, Suk JE, Griffiths P, van de Laar MJ. Human immunodeficiency virus in injecting drug users in Europe following a reported increase of cases in Greece and Romania, 2011. Euro Surveill. 2011;16. pii: 20032.

9. Paraskevis D, Nikolopoulos G, Tsiara C, Paraskeva D, Antoniadou A, Lazanas M, Gargalianos P, Psychogiou M, Malliori M, Kremastinou J, Hatzakis A. HIV-1 outbreak among injecting drug users in Greece, 2011: a preliminary report. Euro Surveill. 2011;16. pii: 19962.

10. Amon JJ, Garfein RS, Ahdieh-Grant L, Armstrong GL, Ouellet LJ, Latka MH, Vlahov D, Strathdee SA, Hudson SM, Kerndt P, Des Jarlais D, Williams IT. Prevalence of hepatitis C virus infection among injection drug users in the United States, 1994-2004. Clin Infect Dis. 2008;46:1852-1858.

11. Des Jarlais DC, Diaz T, Perlis T, Vlahov D, Maslow C, Latka M, Rockwell R, Edwards V, Friedman SR, Monterroso E, Williams I, Garfein RS. Variability in the Incidence of Human Immunodeficiency Virus, Hepatitis B Virus, and Hepatitis C Virus Infection among Young Injecting Drug Users in New York City. Am J Epidemiol. 2003;157:467-471.

12. Kruse GR, Barbour R, Heimer R, Shaboltas AV, Toussova OV, Hoffman IF, Kozlov AP. Drug choice, spatial distribution, HIV risk, and HIV prevalence among injection drug users in St. Petersburg, Russia. Harm Reduct J. 2009;6:22.

13. Murrill CS, Weeks H, Castrucci BC, Weinstock HS, Bell BP, Spruill C, Gwinn M. Age-specific seroprevalence of HIV, hepatitis B virus, and hepatitis $C$ virus infection among injection drug users admitted to drug treatment in 6 US cities. Am J Public Health. 2002;92:385-387.

14. Altay T, Uskun E, Akcam FZ. Seroprevalence of hepatitis B surface antigen and its correlation with risk factors among new recruits in Turkey. Braz J Infect Dis. 2012;16:339-344.

15. Toy M, Onder FO, Wormann T, Bozdayi AM, Schalm SW, Borsboom GJ, van Rosmalen J, Richardus JH, Yurdaydin C. Ageand region-specific hepatitis $B$ prevalence in Turkey estimated using generalized linear mixed models: a systematic review. BMC Infect Dis. 2011:11:337. 